Indian air lines, which most unfortunately meant that the group could not get to Kashmir as planned, the tour did provide viewing of much of India's most exciting wildlife in some of her most beautiful sanctuaries. Certainly everyone enjoyed an excellent holiday.

\title{
Kenya Tour
}

The next East African tour, planned for three weeks in January/ February 1972, will break new ground for FPS in Kenya, taking in the Watamu Marine National Park and Lamu on the Indian Ocean, the Shimba Hills, Tsavo East, Lake Magadi and Lake Rudolph. We also have plans for a walking safari in northern Kenya. This article describing some of these places is based on a prospecting visit by the Hon Secretary and the Editor in January/February this year.

Forty sable antelopes, with gleaming chestnut coats, grazing over a hillside, were the star turn of the new Shimba Hills National Reserve, only twenty miles from Mombasa and the Indian Ocean. They were of all ages and sizes, from the small calf to one splendidly impressive black adult bull, and under a nearby tree we came upon three new-born ones, trying to pretend they were not there. This beautiful small reserve of wooded hills and steep valleys was created largely to safeguard the sable - there are about a hundred there - for this is one of only two populations left in Kenya.

Kenya National Parks have started on a policy of reintroducing some of the animals that have disappeared from these hills, and in a large enclosure we saw the first batch of roan that are being brought in, large antelopes easily recognised by their extraordinary 'spectacled' appearance. These 20 animals were due to be released in a week or two, and another batch brought in for acclimatisation. By next year it should be possible to watch them at large in this reserve. The roan, too, is a sadly reduced animal in Kenya, and these were captured by John Seago for the East African Wildlife Society (a project to which FPS contributed) in the Ithanga Hills, in the vast Tana Ranch in northern Kenya, where they are completely surrounded by cultivation (and poachers), and increasingly restricted as more and more farmer-settlers move in.

The third large and rare antelope which we expect the 1972 party will see is the forest-dwelling bongo, one of the most difficult to see. To everyone's astonishment the new Treetops-type lodge on the edge of the Aberdare Forest, the Ark, has succeeded in attracting these extremely shy animals to its salt-licks, and in considerable numbers. Here the party will spend a night - and all things are possible as well as bongo.

The Watamu and Malindi National Parks on the Indian Ocean have been created to safeguard the superb coral gardens and the beautiful and colourful fish. As a scene of natural beauty there is nothing to surpass it. Floating on the surface with goggles and schnorkel you can become a part of this superb scene, with fish of unbelievably brilliant colours, and varied shapes and sizes, completely unafraid and even swimming to look at you; even those who prefer to keep dry can watch the scene from glass-bottomed boats. And everywhere there are small 


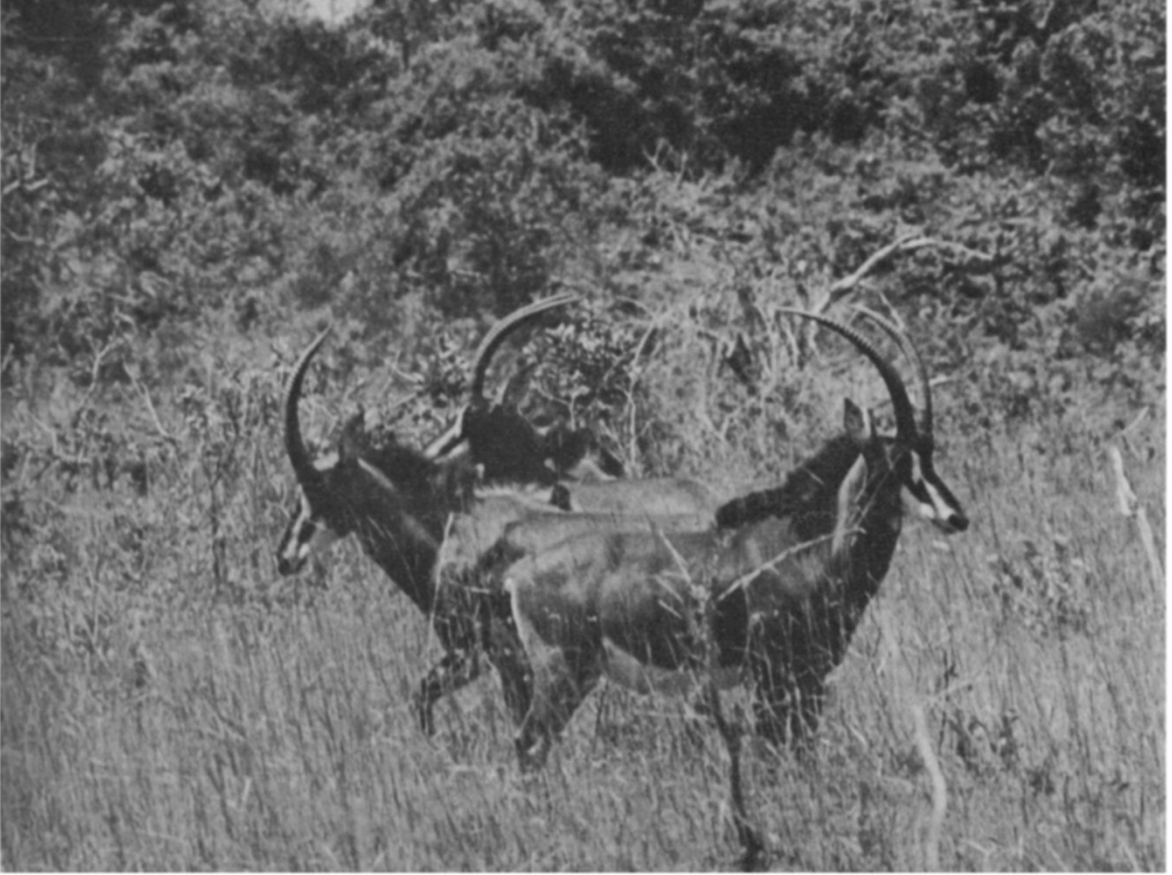

reefs that will reward the lone swimmer. At Watamu, where the 1972 party will spend four days, carefully timed to get the low tides at the calmest time of day, there is the mangrove-lined Mida Creek for waders, the Gedi National Park for ruins (a 16th-century Portuguese city), the Sokoke Arabuko Forest, where we watched the extraordinary and delightful elephant shrews dashing about noisily in the dry leaves of the forest floor, and always, of course, the superb bathing. From Watamu, too, a short flight up the coast takes you to the old Arab island town of Lamu, where there are no cars and the tourist tide has not yet arrived, and we even have hopes of dugong.

The Tsavo East National Park, scene of so much controversy over the elephants, has one of the most spectacular lodges in East Africa, the new Voi Lodge. Perched up on the face of a cliff, with boulders coming up in the hall floor, it looks out over the vast plains of eastern Tsavo, while at the foot of the cliff are two waterholes, gently floodlit at night, where you can watch impala as you breakfast, kongoni at lunch, zebras with your after-dinner coffee and black rhinos as you lie in bed. (We did all these.) Out on the plains the excitements included the elegant gerenuk and lesser kudu; in the Galana river crocodiles and hippos, herons and ibises, egrets and Egyptian geese, and, of course, elephants, lazily uprooting and chewing succulent clumps of grass.

For the last week the party will have a choice of two routes. One party will fly to Lake Rudolph in the north, then fly to the beautiful Samburu park, and finally to the Nakuru park. The other party will visit Keekorok in the Mara plains - still one of the finest areas in East Africa for the enormous numbers of plains animals - and three Rift Valley lakes - Nakuru, Naivasha and Magadi, the last one taking in the small and fascinating prehistoric site of Olorgesaile.

Lake Nakuru, now a national park, is not new ground for FPS 
parties, but it has changed considerably since we last visited it. The birdlife still provides the most staggering and wonderful spectacle flamingos by the million, pelicans in hundreds, other birds in thousands, to make it one of the richest lakes in the world. But now, thanks to protection, there are also quite considerable herds of antelopes, especially bushbuck and waterbuck grazing the open shores. Among the trees we saw the beautiful black and white colobus monkey, while the spectacle of the courtship display of a pair of secretary birds - a quite fantastic sight - was only exceeded by the flamingos' mass courtship display - groups of 60 or 70 birds, heads and long pink necks erect, with neck feathers fluffed out to appear dark, rich pink, all shuffling rapidly through the water in a tight pack that appeared to move as one bird. The photographer's dream!

\section{The Baharini Station}

Nakuru is the scene, too, of one of the bravest and most imaginative conservation projects. All who read Sir Landsborough Thomson's article in the last ORYX about the pollution threat to Lake Nakuru will applaud (and we hope support) John Hopcraft's plans for a research station and education centre on the lake shore, with a safari lodge (under separate management); profits from the last it is hoped will eventually finance the station. John Hopcraft was born beside the lake, and he is determined to save it from the very real dangers that threaten to destroy it.

Also to be visited are Tsavo West, Amboseli and the ever-rewarding Nairobi national park. Nairobi gave us one of the most satisfactory sights of our tour - three young cheetahs lolling under a tree quite close to the track - and not another car in sight for the 20 minutes we stayed there (it was lunchtime!) Cheetahs have become much easier to see in this park - we heard of cubs playing round and even on the visitors' cars. Just the place to use up all your film in one afternoon!

\section{Walking Safari}

At the same time as this FPS party is in Kenya we should like to organise a small party to go on a partly walking safari with tented camps. This would include the Meru Reserve, in northern Kenya, where there is a lot of game but no lodge at present, and consequently fewer people.

We should be glad to hear from any members who would be interested in either of these tours, so that we can have some idea of the numbers we can expect. Please write to Miss Giles.

\section{Land Rover for Baharini}

The FPS has received $£ 500$ from an anonymous donor for the purchase of a Land Rover for the Baharini Research Station on Lake Nakuru, (see above) and has itself given $£ 100$. Before being handed over to Baharini the vehicle will be used for three months this summer by a group of young scientists studing hippopotamus in the Serengeti National Park in Tanzania. 